У,AK 347.97/.99

ББК 67.71

DOI 10.22394/1682-2358-2019-1-26-32

A.R. Isakov, Candidate of Sciences (Law), Docent of the Constitutional and Administrative Law Department, Kabardino-Balkarian State University named after H.M. Berbekov

M.M. Tochieva, master's student of the Constitutional and Administrative Law Department, Kabardino-Balkarian State University named after H.M. Berbekov

\section{FORMING JUSTICES \\ OF THE PEACE \\ IN FOREIGN \\ COUNTRIES: \\ THE EXPERIENCE \\ OF THE UK \\ AND FRANCE}

Forming justices of the peace in a number of foreign countries is analyzed. The process of historical formation of local courts, their role in the overall judicial system, the legal basis of their activities, the terms of reference are considered. The modern judicial system in Great Britain and France is studied. The possibility of using positive experience of foreign countries in this field within the domestic legal reality is proposed.

Key words and word-combinations: justices of the peace, magistrates, judicial system of Great Britain, judicial system of France.
A.P. Исакоһ, кандидат юридических наук, дочент кафедрь конститучионного и административного праља Кабардино-Балкарского государственного университета им. Х.М. Бербекова (email: isaslan@mail.ru)

M.M. Точиева, магистрант кафедрь конституционного и административного права Кабардино-Балкарского государственного универcumema uм. X.М. Бербекова (email: madina95t@ gmail.com)

\section{СТАНОВАЕНИЕ МИРОВОЙ ЮСТИЦИИ В ЗАРУБЕЖННЫХ СТРАНАХ: ОПЫТ ВЕАИКОБРИТАНИИ И ФРАНЦИИ}

Аннотациия. Анализируется становление мировой юстиции на опыте ряда иностранных государств. Рассматривается процесс исторического формирования местных судов, их роль в общей судебной системе, правовые основы их деятельности, круг полномочий. Изучается современное судоустройство Великобритании и Франции. Предлагается возможность использования в рамках отечественной правовой действительности позитивного опыта зарубежных стран.

Ключевые слова и словосочетания: мировая юстиция, магистраты, судебная система, Великобритания, Франция.

B рамках отечественной судебной реформы, важнейшая задача которой состоит в повышении эффективности деятельности мировых судей, преАставляется целесообразным рассмотрение зарубежного опыта 
правового регулирования в Аанной сфере. В большей части развитых стран в процессе исторического развития сформировались институты местных судов, роль которых в различных государствах опредемялась подобными функциями. Анациз истории формирования зарубежных судебных систем позволиц в становлении мировой юстиции выдемить Аве модели [1] .

Согласно первой модели, получившей название англосаксонской (английской), организационно-правовой статус мировых судей как представителей местного суда обладает и общими свойствами, присущими еАиной судебной системе государства, и специфичными, выступая в роли ее особенной части [2] . В соответствии со второй моделью мировой суА выступает в качестве составной части, нижнего звена системы судов общей юрисдикции.

Первоосновы мировой юстиџии зародились в Англии [3, с. 198]. Стабильность ее правовой системы в течение диительного исторического периода дает возможность проследить парадигму становления англосаксонской правовой системы. В результате неэффективной деятельности средневековых шерифов по борьбе с преступностью возникла объективная необходимость перераспределения полномочий в сушествовавшей системе судебных органов в пользу мировых судей, которые в соответствии с Королевской прокламацией 1195 г. именовались помощниками шерифов, «рыџарями мира» (в XIV в. - «стражами мира»). Существенным актом, наделившим мировых судей судейскими полномочиями и определившим их основные задачи, был Глостерский Статут 1278 г. [4, с. 2].

С течением времени роль и полномочия мировых судей возросли, вплоть Ао их наделения контрольными функциями даже по отношению к шерифу в случае Аолжностных змоупотреблений [5, с. 35]. Верховенство судей наА шерифами бымо окончательно закреплено Актом 1461 г., в котором устанавливалось, что все обвинительные заключения и представления, обычно выносившиеся шерифом в проџессе председательствования на сессиях кажАой сотни в своем графстве в отношении таких мелких правонарушений, как Араки и скандалы, в будущем передаются судьям.

С 50-60-х годов XIV в. судьи получили четкое определение не только в качестве основной миротворческой силы, но и как главный инструмент местного самоуправления. В обычную практику вошла передача им всех подобных административных полномочий. В период с конџа XIV в. по 1640 г. полномочия мировых судей в ряде областей существенно расширились. Так, управменческие функции мировых судей прослехиваются в их контроле наА безАомными, которым разрешалось попрошайничество в пределах только своих округов. Отслеживание соблюдения данных норм входияо в компетенцию мировых судей. Расширение полномочий судей распространилось также на регулирование торговли и промышленности. Во время правления Генриха VIII за судьями закрепцямась обязанность по содержанию дорог и мостов. В XVIII в. полномочия английских магистратов Аостигли пика и распредемялись по нескольким уровням.

Наивысший уровень - четвертные сессии, охватывавшие все магистраты округа, после 1689 г. они стаци высшим органом власти округа и осуществляли основную часть административно-хозяйственных Аел. На Аругом уровне 
проводицись встречи групп магистратов в конкретном населенном пункте. Они подраздемялись на специальные и мелкие сессии. Специальные сессии представмяли собой ежемесячные совещания магистратов в конкретных районах страны. В своей административной роли магистраты отвечали за организацию округа. Контроль магистратов наА местными чиновниками был установмен еще до Гражданской войны, но в XVII-XVIII вв. этот контроль усилился. Например, в 1662 г. прерогатива назначения окружных констеблей была передана мировым судьям, а по закону, принятому в 1691 г., им делегировались полномочия по назначению инспектора автомобильных Аорог.

Таким образом, период становления мировых судов в Англии охватывает обширный исторический период, анализ которого позволяет выделить опреАеленные особенности раннего развития магистратов, отражающие суть ангцосаксонской модеми построения мировой юстиции. МежАу 1361 и 1640 гг. круг полномочий, возложенных на мировых судей, вырос до уровня юрисАикции, охватывавшей практически за все аспекты местного самоуправления. Подобное развитие событий происходицо в соответствии с закономерностями социально-политического развития в тот периоА. В частности, рост магистратов был обусловлен увеличением численности Аворянства. Функция магистратов как властной базы дворянства усицилась в XVIII в. и оказала значительное вмияние на события в XIX в.

B XIX столетии магистраты претерпели трансформацию, в ходе которой цишились большей части аАминистративных полномочий и приняли современную форму суда низшей инстанции правосудия. Межау 1828 и 1835 гг. бым принят ряд актов, положивших конец Аоминированию местного самоуп-

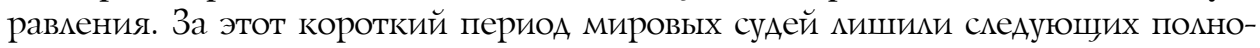
мочий: контромя за продажей спиртных напитков; проверки хлопковых заводов; управления автомагистрацями; управцения тюрьмами, которое было поставлено под более строгий контроль Министерства внутренних дел; наАзор за бродяжничеством делегировался выборным органам (попечительским советам).

В современной Англии согласно Закону «О суде 1952 г. Аействует самая многочисленная и наиболее попуяярная категория судов - магистратские суды [4]. В них вершат правосудие в большинстве своем непрофессионалы, без юридического образования. Магистратским является суА, состоящий из одного или нескольких мировых судей, Аействующих на основании закона, или в сику поручения, или на основании общего права. Английские магистратские суды имеют уголовную, гражАанскую юрисдикцию и юрисдикцию по Аелам несовершеннолетних.

Основанный более 650 мет назад магистрат признан неотъемлемой частью судебной власти Англии и Уэльса. По состоянию на апрель 2016 г. насчитывамось 17552 служащих магистратов, известных как «судьи мира», или «справедливые судьи» [6]. Магистраты занимаются более чем 90\% уголовных дел и значительной частью некриминальной работы, в том числе по делам о семейном праве. В суде они обычно заседают как группа из трех человек при подАержке обученного юрисконсульта, который явмяется помощником судей.

Вторая модель мирового судопроизводства свойственна Франции. На протяжении всей истории существования судебная система страны менялась па- 
рамлельно Аинамически развивающемуся обществу. Первоначально судебная власть конџентрировалась в руках короля или киџ, уполномоченных от его имени. Считалось, что они отражают волю Бога. Образ короця-судьи явцялся сильным символом. В силу распространенности теологических преАставлений о сущности вмасти монарха в период СреАневековья решения правитемя облаАали статусом справедиивых и истинных волеизъявлений. Например, Ауи IX, более известный как Святой Ауи - яркий пример в этом отношении, так как умело пользовался репутацией справедливого правителя.

В 1604 г. статус судей стал наследуемым. Аенежное содержание судей было незначительным, поэтому основное бремя по их обеспечению перекладывамось на стороны спора, в связи с чем доступ к правосудию сушественно ограничивался. Запутанная система судов, а также многочисленные возможности Аля апемляции приводици к затягиванию разбирательств, вплоть до десятилетий или Ааже переходить от оАного поколения к Аругому.

В течение XVIII в. предпринималось несколько попыток рационацизировать организацию судов. ОАнако из-за противодействия оппозиџии предложенные реформы потерпели неудачу. Извлекая уроки из недостатков королевской системы правосудия, Французская революџия 1789 г. привела к реформам как в судебной организации, так и в статусе судей, сметая монархические и религиозные концепции судебной системы.

Руководствуясь идеями Просвещения, французские революционеры 26 августа 1789 г. приняли Аекмарацию прав человека и гражданина [7] и установили основные принципы, которые мегли в основу законодательства и судебной системы. В Законах от 16 и 24 августа 1790 г. измагались основные принципы, на которых французская судебная система базируется и сегодня: разделение межАу двумя типами судов (аАминистративные и «судебные»); право на апемляцию; равенство перед законом; судебное разбирательство, осуществляемое бесплатно (судьи отныне оплачиваются государством); введение присяжных заседателей по уголовным делам [8, с. 107].

По гражданским делам функционировали два уровня судов. На первом уровне juges de paix (мировые судьи) пытались примирить стороны в спорах по бытовым вопросам. Следующий уровень - трибунац округа - вкцючал пять избираемых судей и публичного министра, они выступали в качестве апемляционного суда дмя решений, вынесенных мировыми судьями. Жалобы на решения трибунала округа направцялись в сосеАний аналогичный орган, выбираемый сторонами, так как в этот период не было вышестоящего суда.

Система уголовного правосудия быма разделена на три типа судов, каждый из которых рассматривац конкретную категорию правонарушений. Так, во всех муниџипалитетах существовали полиџейские трибуналы Аля разбирательств по незначительным правонарушениям. СуА проходил под председательством судьи трибунала округа. На уровне кантонов имелись трибуналы помицейской коррекции дмя борьбы с более серьезными правонарушениями. Уголовные трибуналы создавались в главном городе каждой области и состоями из четырех судей и жюри в количестве двенадџати граждан, выбиравшихся жребием. В процессе развития эти учрежжения стали судами присяжных. 
Tribunaux d'appel (апемяџионные суды) и кассационный трибунал, также созданные в 1790 г., Аолжны были обеспечить соблюдение закона при принятии решений нижестоящими судами. Кассаџионный суд трибунала не обладал полномочиями, которыми пользуется современный Cour de Cassation (Высший Апеммяционный СуА).

Аостаточно существенные изменения в правовой жизни Франщии произошии с приходом к власти Наполеона Бонапарта в 1804 г. Он иниџиировац ряд крупных нововведений в отношении отдельных институтов и права в цемом. Именно благодаря ему во Франџия были приняты Гражданский кодекс, или Наполеоновский кодекс (1804), Гражданский проџессуальный кодекс (1806), Торговый кодекс (1807), Уголовно-процессуальный кодекс (1808) и Уголовный кодекс (1810).

Организация гражданского правосудия была реформирована наряду с метоАом назначения судей. Отныне они больше не избирались, а назначались правительством, а организация судов становилась гораздо более иерархичной. На самом низком уровне мировые судьи сохранялись на уровне кантона, осуществляя роли арбитров и посредников. На следующем уровне в кажАом городском округе организовывался гражданский трибунал (гражданский суА), состоящий из трех судей. Их юрисдикџия была общей в первой инстанџии, они также пересматривали решения, вынесенные мировыми судьями. Аалее следовали апелмяџионные трибуны, которые в 1804 г. стали апемялуионными судами, обычно с юрисдикцией над тремя областями. Высшая судебная инстанџия - Кассационный трибунал - в 1804 г. был переименован в Кассаџионный суа. Он сохранил юрисдикщионные полномочия револющионного периода, а также имел Аисциплинарные полномочия по отношению ко всей судебной системе.

В Уголовно-процессуальном кодексе 1808 г. впервые изложены принципы уголовного судопроизводства и значительно измененные процедуры. Так, на прокуратуру возлагалась ведущая роль в инищиировании судебного преслелования, поскольку ее главной функщией было выявмение и доказывание вины правонарушителей в суде.

В период после падения Наполеона до середины XX в. организация гражданских и уголовных судов не претерпела существенных изменений. Тем не менее постепенно внеАрялась в жизнь система административных судов, структурно устроенных по образу гражданских судов. Основные изменения произошии в 1958 г. с приходом к власти Шарля де Гомяя. Судебная система подверглась реформе с учетом демографических изменений, улучшения транспортной инфраструктуры, совершенствования методов коммуникации и судебной деятельности.

Из-за увеличения объема судебной нагрузки в некоторых районах были созданы новые апемляџионные суды с расширением их полномочий. В Аальнейшем в их функщии вошло рассмотрение жалоб, возбужденных против судебных решений, вынесенных всеми судебными инстанџиями (судами первой инстанџии), включая специализированные суды. Мировые суды заменялись tribunal d'instance (районными судами), созданными в каждом районе. Tribunal de grande instance (высокий суА) заменил tribunal civil (гражАанский суА) в главном городе каждого округа. Судебная система окончательно была унифиџирована, и всем ее членам предоставцялся единый статус. 
В настоящее время организация французских судов основана на нескольких принщипах (разделении административных органов и судов, праве на апемляџию, беспристрастности и т.п.), обеспечивающих соблюдение основных свобод. Все суды делятся на два основных типа (суды общей юрисдикџии, то есть гражданские и уголовные суды, и административные), что способствует обеспечению соблюдения прав граждан (рисунок).

Гражданские и уголовные суды обладают полномочиями по рассмотрению споров между частными мицами и по уголовным делам. Так, гражданские суды рассматривают споры между арендодатемем и арендатором, потребитемями и производителями, о наследовании и т.п., но не налагают штрафов. Уголовные суды наказывают за преступления тех, кто причиняет вреА Аругим, наносит ущерб имушеству или обществу в целом. Административные суды рассматривают споры межАу частными мицами и государством, местным органом власти, государственным органом, которые предоставмяют государственные услуги [9, с. 162].

Судебная реформа, проведенная в 2007 г., уменьшила число судов с 1190 до 863. В рамках всей судебной системы мировым судьям подведомственны гражданские дема, связанные с претензиями, не превышающими 4000 евро, и незначительные правонарушения (например, нарушения прави^ дорожного движения).

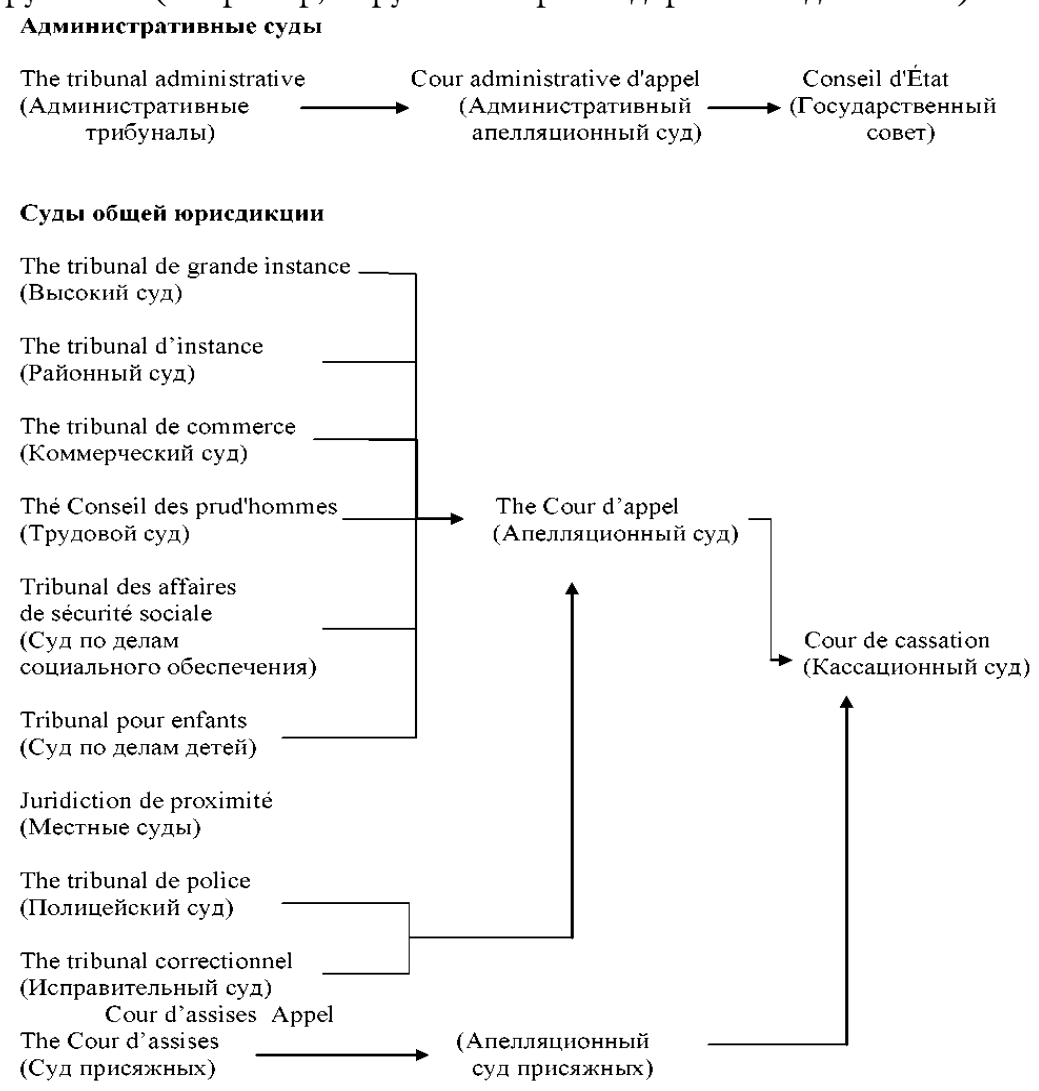

Судебная система Франции

Вестник Поволжкского института управления

- 2019. Том 19. № 1 
Итак, богатый исторический опыт реформирования организационно-правового статуса мировых судей в зарубежных государствах, на наш взгляд, может служить источником заимствования наиболее удачных преобразований в рамках отечественной правовой действительности.

Аля российской правовой действительности весьма актуальна проблема большой загруженности судей различных уровней, что усугубцяется ежегоАным увеличением количества рассматриваемых дел. В связи с этим представмяет интерес созданная и действующая разветвленная система узкоспециализированных судов во Франџии, которая позволяет равномерно распределить нагрузки межАу ними, существенно облегчает работу самих судей путем сужения круга подсудных дел на основе их правовой природы.

\section{Библиографический список}

1. Лонская С.В. Типология мировой юстиции // Вестник Балтийского федерального университета им. И. Канта. Сер.: Гуманитарные и общественные науки. 2012. № 9. С. 7-12.

2. Чулкова Т.В. Англосаксонская модель мировой юстиции // Инновационная наука. 2018. № 5-2. C. 72-76.

3. Назаров И.В. Судебная система Великобритании и ее реформирование в связи с членством в Европейском союзе // Проблемы законности. 2011. С. 198-207.

4. Рассказов Л.П. Англосаксонская правовая семья: генезис, основные черты и важнейшие источники // Научный журнал КубГАУ. 2015. № 105(01). С. 1-15.

5. Уолкер Р. Английская судебная система. М., 1980.

6. Courts and tribunals judiciary. URL: https://www.judiciary.uk

7. Декларация прав человека и гражданина 1789 г. URL: http://larevolution.ru/declaration.html

8. Омельченко O.A. Всеобщая история государства и права: учебник: в 2 т. 3-е изд., испр. M., 2000. T. 2.

9. Исаков А.P. Зарубежный опыт оптимизации взаимодействия должностных лиц и граждан // Правозащитная политика в современной России: К 20-летию Основного Закона государства: сборник по материалам круглого стола и Всероссийской научно-практической конференции, Ульяновск, 9 декабря 2013 г. Ульяновск, 2013 С. 160-164. 